Studia nad Autorytaryzmem i Totalitaryzmem 43, nr 2

Wrocław 2021

https://doi.org/10.19195/2300-7249.43.2.1

\author{
ROMAN BÄCKER \\ ORCID: 0000-0002-3796-3711
}

Uniwersytet Mikołaja Kopernika w Toruniu

rombacker@wp.pl

JOANNA RAK

ORCID: 0000-0002-0505-3684

Uniwersytet im. Adama Mickiewicza w Poznaniu

joanna.rak@amu.edu.pl

\title{
Challenging the theoretical framework of the totalitarian syndrome*
}

\section{CHALLENGING THE THEORETICAL FRAMEWORK OF THE TOTALITARIAN SYNDROME}

\section{Summary}

The article is of methodological nature and aims to evaluate the content validity of Carl Joachim Friedrich and Zbigniew K. Brzezinski's totalitarian syndrome, that is, the extent to which this theoretical framework accurately represents the social phenomena to which it refers.

It introduces the critical analysis of the individual concepts extracted from the totalitarian syndrome as the indicators of totalitarianism and the model as a whole as a research tool for measuring political regimes. The paper begins with the discussion on an alternative concept of totalitarianism formulated by Nicholas Timasheff to illustrate the context in which the authors of the theoretical categories of totalitarianism created them. Then, the article goes on to analyze the nature and major characteristics of Friedrich and Brzezinski's totalitarian syndrome as well as these reviews of Totalitarian Dictatorship and Autocracy, which addressed the validity of the model. Social scientists have widely criticized Friedrich and Brzezinski's totalitarian syndrome. The most serious objection concerns the non-specific essential features collected and combined to define totalitarianism. The taxonomic nature of the model has allowed researchers, who blindly adopted the framework, to classify discretionarily political regimes of numerous states as totalitarian. Friedrich and Brzezinski

* This paper is a result of research project Contentious Politics and Neo-Militant Democracy. It was financially supported by the National Science Centre, Poland (grant number 2018/31/B/ HS5/01410). While working on the article, Joanna Rak was supported by the Foundation for Polish Science (FNP) in the form of START Scholarship and Barbara Skarga Scholarship. 
failed to advance any clear criteria for coding. They did not establish a line between meeting and not meeting the listed essential features. Furthermore, it is unknown what character the features enumerated under this syndrome have. This generates a question if the six "indicators" are essential, distinctive, significant, co-decisive, contours, features, factors, frames, pillars, or mechanisms. Although Friedrich and Brzezinski's totalitarian syndrome fulfilled a prominent educational role mostly for US citizens by showing that there could be social worlds completely different from those in which one lives, the proposed understanding of totalitarianism is insignificant in defining such regimes. This theoretical framework inaccurately represents the social phenomena to which it refers. The paper finishes with the argument against applying the syndrome to scrutinize political regimes because of its considerably limited content validity.

Keywords: totalitarianism, totalitarian syndrome, Carl Joachim Friedrich, Zbigniew K. Brzezinski, non-democratic regime, theoretical model, content validity.

\section{Introduction}

In their famous Totalitarian Dictatorship and Autocracy, Carl Joachim Friedrich and Zbigniew K. Brzezinski formulated the general model of totalitarian dictatorship and of the society it has created by drawing upon generally known and acknowledged factual data. ${ }^{1}$ It means that they made a generalization to formulate a theoretical category of totalitarianism. However, this generalization did not rest on methodologically informed research and thus failed to meet the contemporary social sciences standards. Moreover, the researchers decided not to seek to include any explanatory factors in their theory and therefore avoided accounting for the sources of totalitarianism. Accordingly, the approach comes down to laying down a set of criteria for the differentiation between totalitarian and other political regimes. ${ }^{2}$ Nevertheless, despite many enthusiastic reviews and numerous papers released by Friedrich and Brzezinski's followers, ${ }^{3}$ one should avoid taking for granted the analytical effectiveness of the theoretical totalitarian syndrome framework. The following article argues that researchers studying totalitarianism should question and challenge this model due to the construct content validity.

Validity is a fundamental criterion for assessing the quality of any analytical tool. The construct content validity determines how accurately a measure conforms to theoretical expectations. Any measure exists in a particular theoretical context and thus sheds light on relationships with other constructs that may be

${ }^{1}$ C.J. Friedrich, Z.K. Brzezinski, Totalitarian Dictatorship and Autocracy, Cambridge, MA 1965, p. xi.

2 B.L. Alpers, Dictators, Democracy, and American Public Culture: Envisioning the Totalitarian Enemy, 1920s-1950s, Chapel Hill-London 2003, p. 253.

3 See e.g., A.J. Groth, “The 'isms' in totalitarianism”, American Political Science Review, 58, 1964, no. 4, pp. 888-901; I.K. Feierabend, "Expansionist and isolationist tendencies of totalitarian political systems: A theoretical note", The Journal of Politics 24, 1962, no. 4, pp. 733-742. 
anticipated and interpreted within this framework. ${ }^{4}$ The literature on the methodology of social sciences fails to provide researchers with any foolproof procedures to determine content validity. The use of validation methods must depend on the situation. ${ }^{5}$ The most common are triangulation and respondent validation. Nevertheless, while the first one may be biased by methodological assumptions formulated by researchers, the second may be equally biased because of stereotypes and myths concerning the phenomenon that is to be measured.

This article offers a critical analysis of the individual concepts extracted from the totalitarian syndrome as the indicators of totalitarianism, and the whole model as a research tool for measuring political regimes. The paper is of methodological nature and aims to evaluate the content validity of Friedrich and Brzezinski's totalitarian syndrome, that is, the extent to which this theoretical framework accurately represents the social phenomena it refers to. ${ }^{6}$

The article commences with the discussion on an alternative concept of totalitarianism formulated by Nicholas Timasheff. Similarly to Friedrich, Timasheff delivered his speech for the first time during the conference at the American Academy of Arts and Sciences in March 1953. This theoretical approach initiates the analysis because it allows us to vividly illustrate the context in which the authors of the theoretical categories of totalitarianism created them. Hence, the article discusses the nature and major characteristics of Friedrich and Brzezinski's totalitarian syndrome as well as those reviews of Totalitarian Dictatorship and Autocracy which addressed the validity of the model. The paper finishes with the evaluation of the construct content validity.

\section{Nicholas Timasheff's theoretical approach towards totalitarianism}

Leon Petrażycki's student, Nicholas Timasheff, was one of the most outstanding Russian scholars. In 1920, Timasheff was forced to emigrate to the USA, where he became a professor at Fordham University, specializing in the sociology of law. Simultaneously, he was a qualified expert in the methodology of social sciences. During the conference organized by Carl Friedrich in 1953, he delivered the first paper: "Totalitarianism. Despotism. Dictatorship," which contributed to the studies

${ }^{4}$ K.F. Punch, Introduction to Social Research: Quantitative \& Qualitative Approaches, Los Angeles-London-New Delhi 2014, p. 240.

5 Ibidem. See also: J.L. Sullivan, S. Feldman, Quantitative Applications in the Social Sciences: Multiple indicators, Thousand Oaks, CA 1979, p. 36; S. Kvale, "The social construction of validity", Qualitative Inquiry 1, 1995, no. 1, pp. 19-40.

6 D. Silverman, Interpreting Qualitative Data, Los Angeles-London-New Delhi 2014, p. 326. 
on non-democratic regimes by distinguishing three types of state functions. ${ }^{7}$ The first is the function of defending one's own rights. All states fall within this criterion on a continuum between extremely peaceful and radically aggressive models. The second type is the protective function, meant to maintain law and order. Timasheff claims that in this case, states can be placed on a continuum between two ideal kinds: Rechtsstaat (defined as a due process of law, although the term "the rule of law" is more known today) and a despotic state. In the latter case, however, the adequate term is the "prerogative state" (Massnahmenstaat), known in American literature since $1941 .^{8}$ According to Timasheff, the position of states on this continuum can be determined by evaluating the average strength of applied criminal sanctions. This indicator, however, is inadequate to dealing with social aspects of political regime continuance, mostly because of the distortions in the form of the social (non-) conformism level and the scope of possessed and employed means of social control.

The third type of state function is auxiliary, and therefore does not concern the first two kinds. In this case, a continuum is defined by the liberal order, where the state does not perform such functions, and the totalitarian one, in which the state regulates all possible areas of life. ${ }^{9}$ Nevertheless, here the word "totalitarianism" is not entirely appropriate. It would be adequate to the nature of the considered continuum to replace "totalitarianism" with the word "total" in the meaning "holistic." If we stayed within the significantly broadened semantic field of the word "totalitarianism," then we would have to apply it to define every comprehensive social system based on one principle that regulated it. Such as, for example, a free market system expanding to all areas of social life. The analytical effectiveness of the model is, therefore, considerably limited.

Irrespective of the above critical remarks, Timasheff's line of thinking should be rated very highly. States, and more broadly all political entities, can be on a continuum between two antinomic ideal types. This is the fulfilment of given features that results in locating any entity on the continuum. The features are measurable within one or more significant criteria. In this case, one can measure the position of some political entities in relation to others (e.g., the extent to which a political system is totalitarian). An equally interesting research field is measuring the size and vector of the evolution of given political entities, i.e., their detotalitarization or approaching the ideal type of totalitarianism. Timasheff himself, in turn, points out a different research trail - that is, checking whether there are relationships between the places occupied by given entities on different continuums. ${ }^{10}$

${ }^{7}$ N. Timasheff, “Totalitaryzm. Despotyzm. Dyktatura”, [in:] Totalitaryzm. Materiaty z konferencji zorganizowanej przez Amerykańska Akademię Sztuk i Nauk w marcu 1953 r., ed. C.J. Friedrich, Warszawa 2019, pp. 74-75.

8 E. Fraenkel, J. Meierhenrich, The Dual State: A Contribution to the Theory of Dictatorship, Oxford 2017 [1941], p. 3.

9 N. Timasheff, op. cit., pp. $75-80$.

10 Ibidem. 
Note should be taken that the discussion after Timasheff's and Friedrich's speeches at the famous conference on totalitarianism held at the American Academy of Arts and Sciences in March 1953 did not address the issue of understanding the nature of totalitarianism at all. Meanwhile, the dominant debate subject was the uniqueness of this political regime in the 20th century or its universality in history. This problem might be solvable only if the definition of this epiphenomenon is established beforehand. Debaters directly (e.g. Hannah Arendt ${ }^{11}$ ) or indirectly accepted the definition of totalitarianism presented by Friedrich. ${ }^{12}$ One can only assume that it was simply closest to their scientific and life experiences. ${ }^{13}$

\section{The theoretical framework of the totalitarian syndrome}

According to Friedrich and Brzezinski, the totalitarian dictatorships share several essential features. ${ }^{14}$

1. They use an elaborate ideology that offers an official body of doctrine dealing with all relevant aspects of man's existence to which everyone functioning in that society is expected to adhere at least passively. This ideology is concentrated on a perfect final state of mankind. It draws upon a chiliastic claim that the existing society must be rejected and the world for the new one must be won.

2. One man called "the dictator" leads a single mass party. A relatively small percentage of the total population (up to $10 \%$ ) is engaged in the party activity. However, a hard core of them is passionately and unquestioningly devoted to the ideology and ready to support by all means the dissemination of its general acceptance. The party is hierarchically, oligarchically organized and usually either superior to or entirely interwoven with the governmental bureaucracy.

3 . A system of physical or psychic terror exists. Its means are the party and secret-police control, assisting but also supervising the party for its leaders. Terror is usually used against demonstrable "enemies" of the regime and arbitrarily chosen social groups. It systematically misuses scientific advances, especially those of psychology.

4. The party and the government have a technologically conditioned, almost total monopoly of control over all means of efficient mass communication, including the press, radio, and motion pictures.

11 A.L. Gonçalves, "Interpretações do totalitarismo: Hannah Arendt e Friedrich-Brzezinski”, Clareira-Revista de Filosofia da Região Amazônica 4, 2017, no. 1-2, pp. 68-83.

$12 \mathrm{~K}$. von Beyme, "The concept of totalitarianism: A reassessment after the breakdown of communist rule", [in:] The Totalitarian Paradigm After the End of Communism: Towards a Theoretical Reassessment, ed. A. Siegel, Amsterdam-Atlanta 1998, p. 35.

13 N. Timasheff, op. cit., pp. 112-123. See also: K. von Beyme, "Authoritarian regimes — Developing open societies?", [in:] The Open Society in Theory and Practice, eds. D. Germino, K. von Beyme, Dordrecht 1974, p. 109.

14 C.J. Friedrich, Z K. Brzezinski, op. cit., p. 22. 
5. The party and the government have a technologically conditioned, nearfull monopoly on the effective utilization of all weapons for armed combat.

6 . The rules of central control and direction of the entire economy are in force. They are performed through the bureaucratic coordination of previously independent corporate entities, usually incorporating most of other associations and group activities. ${ }^{15}$

It is noteworthy that the researchers added the sixth criterion to this set after the 1953 conference. Brzezinski, who was a student of Friedrich and acted as a secretary for this conference, convinced him that control over the economy is also significant for the totalitarian syndrome.

Both Friedrich and Brzezinski treat this set of five, and later six interrelated criteria as holistic. Thus, the existence of totalitarianism as a political regime is confirmed by the simultaneous occurence of all these criteria rather than the appearance of one or more factors, even in their most extreme forms. ${ }^{16}$

Besides, the authors very clearly emphasize that totalitarianism is a twentiethcentury phenomenon. Its emergence has become possible thanks to new technologies both in the field of mass social communication and in top-down processes of shaping social awareness. ${ }^{17}$

\section{The reviews of Friedrich and Brzezinski's theoretical framework of totalitarianism}

The book Totalitarian Dictatorship and Autocracy has been the subject of numerous academic discussions in major scientific journals. Although as many as eight reviews of this volume were released during the first ten years after its publication, ${ }^{18}$ one may assume that there are many more. However, the importance of the book is determined not by the number of reviews, but by the rank of journals that publish them. Let us list merely a few that took part in the dissemination of remarks about Friedrich and Brzezinski's approach: The American Historical Review (the official journal of the American Historical Association), American Political Science Review (American Political Science Association), World Politics (twice) (Cambridge University Press on behalf of the Princeton Institute for International and Regional Studies), Political Science Quarterly (published since 1886 by the Academy of Political Science), The Review of Politics (Cambridge University Press for the University of Notre Dame), and Problems of Communism (the United States Information Agency), which are among the best political and historical periodicals in the world.

15 Ibidem.

16 Ibidem, pp. 21-22.

17 Ibidem, pp. 18-19.

18 "Content archive of printed periodicals and books", The Unz Review, https://www.unz.com/ print/FriedrichCarl-1956/ (accessed: 12.03.2020). 
The evaluative book reviews range from extremely appreciative ${ }^{19}$ to severely critical. ${ }^{20}$ Carl Emil Schorske (1915-2015) wrote one of the most interesting ones. He was not only a professor at Harvard, among others, but also a head of American intelligence in Europe in the Office of Strategic Service - the predecessor of the Central Intelligence Agency (CIA) - during World War II. Schorske notices only one advantage of the volume: it may function well both as a serious monograph and a student textbook. His criticism mainly concerns the volume's theoretical level. As Schorske indicates, Friedrich and Brzezinski define totalitarian dictatorship in the possibly simplest terms. Although the choice of facts is appropriate, they do not fit into the general scheme. They are, nevertheless, pressed into the appropriate mold. Schorske illustrates this argument with Friedrich and Brzezinski's study of Italy. Despite the army's autonomy from the fascist party, this regime is treated as totalitarian anyway in Totalitarian Dictatorship and Autocracy. In turn, if the factors described by Friedrich and Brzezinski are not fully met, then the given autocracies are not totalitarian according to the adopted taxonomic method of classification. In this case, although not explicit, the suggestion is quite clear: Schorske implies that it would be more analytically effective to adopt the idealization approach initiated by Max Weber. It is considerably more reliable and apt to compare political regimes in terms of the intensity of totalitarianism rather than to arbitrarily decide about a regime - which may only meet constitutive features to some extent - belonging or not belonging to the totalitarian autocracy. ${ }^{21}$

Schorske clearly doubts the sense of adopting the institutional approach and emphasizes: "The a priori institutional approach to totalitarianism [...] cannot come to grips of its dynamics." 22 In addition, this approach seriously hindered the clarification of totalitarian regime's genesis (including intellectual). In turn, the use of institutional perspective and no other theoretical approach significantly reduced the possibilities of understanding the phenomenon of totalitarian thinking. ${ }^{23}$ The gravest allegations include the incorrect selection of a taxonomic analytical tool rather than an idealizational one, and the use of solely the institutional paradigm when other paradigms should have been employed. Although Schorske does not disqualify this book completely, he considers it insufficient for both exploring and explaining the twentieth-century phenomenon of totalitarianism.

The criticism of Leonardo Schapiro from 1972 had a slightly different character. The researcher employed only one term: "factors," to determine the elements

19 See e.g. F.A. Hermens, "Tyranny, past and present", The Review of Politics 20, 1958, no. 2, pp. 257-263; A. Brecht, "Totalitarian Dictatorship and Autocracy by Carl J. Friedrich; K. Zbigniew Brzezinski [a review]", Social Research 24, 1957, no. 4, pp. 482-486 (e.g., "This is the best book we have had so far on totalitarianism as a form of government," p. 482).

20 C.E. Schorske, "Totalitarian Dictatorship and Autocracy. By Carl J. Friedrich and Zbigniew K. Brzezinski. (Cambridge, Mass.: Harvard University Press. 1956. Pp. xii, 346.)”, The American Historical Review 63, 1958, no. 2, pp. 367-368.

21 Ibidem.

22 Ibidem, p. 367.

23 Ibidem, pp. 367-368.

Studia nad Autorytaryzmem i Totalitaryzmem 43, nr 2, 2021

(C) for this edition by CNS 
of the syndrome distinguished by Friedrich and Brzezinski. ${ }^{24}$ Schapiro's criticism of Friedrich and Brzezinski's understanding of totalitarianism is twofold. First, he shows that the definition fails to cover the essential features of totalitarianism. More specifically, according to Schapiro, the syndrome did not cover the entire semantic field of totalitarianism. The researcher names two more features which are worth including in the framework: the theory of world domination and the need for constant efforts to create a state of mass mobilization. In turn, control over coercive measures is, in Schapiro's view, a significant feature typical of every government wishing to stay in power. It is, therefore, not specific to totalitarianism. The second level of criticism concerns the non-specificity of features enumerated in the totalitarianism syndrome. The use of modern technologies only created a difference in the degree and not the type of control over the masses. ${ }^{25}$

Schapiro proposes a radical departure from Friedrich and Brzezinski's totalitarian syndrome. He appeals to readers that "it is time to escape from it." 26 Thus, Schapiro considers this understanding of totalitarianism as completely outdated and unfit for use even after extensive modifications. For the professor from the London School of Economics, specializing in the history of twentieth-century Russia, the most important issue in understanding the concept of totalitarianism was to determine its essential defining features. Schapiro distinguishes four different types of features to show the multifaceted definition of totalitarianism: contours, features, factors, and pillars. Within the conceptual framework of these four characteristic types, the researcher defines the qualities considered specific to totalitarianism.

One ought to remember that the understanding of totalitarianism proposed by Schapiro in further parts of his book was not widely accepted in the world literature for various, also substantive, reasons. ${ }^{27}$

\section{Conclusions}

Social scientists have widely criticized Friedrich and Brzezinski's totalitarian syndrome. ${ }^{28}$ The most serious objection regards the non-specific essential features collected and combined to describe totalitarianism. The taxonomic nature of the model has allowed researchers to discretionarily classify political regimes of numerous states as totalitarian. Friedrich and Brzezinski failed to

${ }^{24}$ L. Schapiro, Totalitarianism, New York-Washington-London 1972, p. 19.

25 Ibidem, pp. 19-20.

26 Ibidem, p. 20.

27 See the criticism of the approach: R. Bäcker, Totalitaryzm. Geneza. Istota. Upadek, Toruń 1992.

28 See e.g. K. Brzechczyn, "Metodologiczny status koncepcji totalitaryzmu a modelowanie dynamiki systemu komunistycznego", [in:] Uwiktania historiografii. Między ideologizacja dziejów a obiektywizmem badawczym, eds. T. Błaszczyk et al., Poznań 2011, pp. 67-84. 
advance any clear criteria for coding. They did not establish a line between meeting and not meeting the listed essential features. In addition, the character of these features is unknown, which raises a question whether the six "indicators" are essential, distinctive, significant, co-decisive, contours, features, factors, frames, pillars, or mechanisms.

An additional factor is the evident lack of full knowledge of the literature on totalitarianism. The obvious source of information on the topic would certainly be Hannah Arendt's texts; however, specialists should have also known the book by Ernst Fraenkel as well as Eric Voegelin's excellent approach towards epistemic apparatuses in totalitarian regimes, which cuts through the assumptions on totalitarian ideology. ${ }^{29}$ Although in references Friedrich and Brzezinski listed Voegelin's The New Science of Politics (Chicago 1952) and Die Politischen Religionen (Vienna 1938), ${ }^{30}$ they did not even mention political gnosis, the core category coined by Voegelin to address the way of thinking typical of totalitarianism. This notion of particular political religion reflects the essence of totalitarian thinking much more accurately than the concept of ideology. ${ }^{31}$ Ideology is non-specific to totalitarianism and may be efficiently produced, distributed, and redistributed in all types of political regimes.

However, perhaps the most important issue is the invalidity of the factors that make up the totalitarian syndrome. The first one, the chiliastic ideology assuming the complete transformation of humanity into an entirely different world, can be interpreted in many different ways. In lieu of chiliastic ideology, Friedrich and Brzezinski might have applied the then widely known category Weltanschauung, ${ }^{32}$ and even better - political gnosis. Applying a literal understanding of the chiliastic ideology, one may conclude that some varieties of liberalism or the religiously justified ways of political thinking (e.g., Christian Democrats) meet the above criterion. ${ }^{33}$ As this argument points out, the first factor is not peculiar to totalitarianism.

There are two ways of interpreting the second criterion: narrowing and broadening. According to the former, if one writes about a "single mass party," then they cannot restrictively classify those countries in which several parties formally exist as totalitarian regimes, even when all are completely subordinated to

29 E. Voegelin, The New Science of Politics: An Introduction, Chicago-London 1987 [1952], pp. $120-121$.

30 They did not refer to: E. Voegelin, "Gnostische Politik”, Merkur 6, 1952, no. 4, pp. 301317.

31 See also: P.W. Gray, "Vanguards, sacralisation of politics, and totalitarianism: Category-based epistemology and political religion”, Politics, Religion \& Ideology 15, 2014, no. 4, pp. 521-540.

32 R. Sackmann, "Democracy, totalitarianism, and dead ends in sociology", Serendipities 2, 2016, pp. 158-177.

33 S.M. Lipset, "Democracy and working-class authoritarianism", American Sociological Review 24, 1959, no. 4, pp. 482-501; V. Tismaneanu, Fantasies of Salvation: Democracy, Nationalism, and Myth in Post-Communist Europe, Princeton, NJ 2009, p. 23. 
the political will of the leader. If we adopt the broadening perspective, then all statocratic authoritarian parties of the first type which managed to remove the opposition from the parliament are considered totalitarian parties.

The system of terror described in the third factor may not exist or manage to occur in incidental cases, and the regime will continue to be totalitarian. Terror appears at the stage of creating the regime, so when it is necessary for its survival, not only to "evaporate" 34 real and potential enemies, but also to completely atomize natural social groups. There is no need for terror in the stabilization phase and there is less and less opportunity for it in the bifurcation period.

The almost complete monopoly of mass communication within the party or government described in the fourth criterion is unimaginable for an American. In the United States of America, no party even has its own newspaper. However, such a monopoly has existed and occurs in many states which one may treat as authoritarian.

In the case of effective control over the means of violence, Friedrich and Brzezinski themselves realized that these measures exist in many states, including Great Britain. ${ }^{35}$ Similarly, the sixth factor, i.e., the control of the entire economy through, for example, bureaucratic coordination, is non-specific to totalitarian regimes. ${ }^{36}$

The six factors defining the totalitarian syndrome have one quality in common: in any case, they are antinomic to solutions, mechanisms, and institutions operating in the USA.

To sum up, Friedrich and Brzezinski's totalitarian syndrome fulfilled a prominent educational role for US citizens. ${ }^{37}$ This theoretical approach revealed that there could be social worlds completely different from those in which one lives. However, Friedrich and Brzezinski's understanding of totalitarianism is insignificant in defining such regimes because of considerably limited content validity.

\section{Bibliography}

Alpers B.L., Dictators, Democracy, and American Public Culture: Envisioning the Totalitarian Enemy, 1920s-1950s, Chapel Hill-London 2003.

Bäcker R., Totalitaryzm. Geneza. Istota. Upadek, Torun 1992.

Beyme K. von, “Authoritarian regimes — Developing open societies?”, [in:] The Open Society in

Theory and Practice, eds. D. Germino, K. von Beyme, Dordrecht 1974.

34 See: G. Orwell, A.M. Heath, Animal Farm and 1984, New York 2003.

35 C.J. Friedrich, Z.K. Brzezinski, op. cit., p. 18.

36 The same point of view see e.g. Kailitz S., "Carl Joachim Friedrich/Zbigniew Brzezinski, Totalitarian Dictatorship and Autocracy, Cambridge 1956”, [in:] Schlüsselwerke der Politikwissenschaft, ed. S. Kailitz, Wiesbaden 2007, pp. 129-132.

37 Compare this assumption with R. Burrowes, "Totalitarianism: The revised standard version", World Politics 21, 1969, no. 2, pp. 272-294. 
Beyme K. von, "The concept of totalitarianism: A reassessment after the breakdown of communist rule", [in:] The Totalitarian Paradigm After the End of Communism: Towards a Theoretical Reassessment, ed. A. Siegel, Amsterdam-Atlanta 1998.

Brecht A., "Totalitarian Dictatorship and Autocracy by Carl J. Friedrich, K. Zbigniew Brzezinski [a review]", Social Research 24, 1957, no. 4.

Brzechczyn K., "Metodologiczny status koncepcji totalitaryzmu a modelowanie dynamiki systemu komunistycznego", [in:] Uwikłania historiografii. Między ideologizacją dziejów a obiektywizmem badawczym, eds. T. Błaszczyk, K. Brzechczyn, D. Ciunajcis, M. Kierzkowski, Poznań 2011.

Burrowes R., "Totalitarianism: The revised standard version", World Politics 21, 1969, no. 2.

"Content archive of printed periodicals and books", The Unz Review, https://www.unz.com/print/ FriedrichCarl-1956/ (accessed: 12.03.2020).

Feierabend I.K., "Expansionist and isolationist tendencies of totalitarian political systems: A theoretical note", The Journal of Politics 24, 1962, no. 4.

Fraenkel E., Meierhenrich J., The Dual State: A Contribution to the Theory of Dictatorship, Oxford 2017 [1941].

Friedrich C.J., Brzezinski Z.K., Totalitarian Dictatorship and Autocracy, Cambridge, MA 1965.

Gonçalves A.L., "Interpretações do totalitarismo: Hannah Arendt e Friedrich-Brzezinski", Clareira-Revista de Filosofia da Região Amazônica 4, 2017, no. 1-2.

Gray P.W., "Vanguards, sacralisation of politics, and totalitarianism: Category-based epistemology and political religion", Politics, Religion \& Ideology 15, 2014, no. 4.

Groth A.J., “The 'isms' in totalitarianism”, American Political Science Review, 58, 1964, no. 4.

Hermens F.A., "Tyranny, past and present", The Review of Politics 20, 1958, no. 2.

Kailitz S., "Carl Joachim Friedrich/Zbigniew Brzezinski, Totalitarian Dictatorship and Autocracy, Cambridge 1956", [in:] Schlüsselwerke der Politikwissenschaft, ed. S. Kailitz, Wiesbaden 2007, pp. 129-132.

Kvale S., "The social construction of validity", Qualitative Inquiry 1, 1995, no. 1.

Lipset S.M., "Democracy and working-class authoritarianism", American Sociological Review 24, 1959, no. 4.

Orwell G., A.M. Heath, Animal Farm and 1984, New York 2003.

Punch K.F., Introduction to Social Research: Quantitative \& Qualitative Approaches, Los Angeles-London-New Delhi 2014.

Sackmann R., "Democracy, totalitarianism, and dead ends in sociology", Serendipities 2, 2016.

Schapiro L., Totalitarianism, New York-Washington-London 1972.

Schorske C.E., "Totalitarian Dictatorship and Autocracy. By Carl J. Friedrich and Zbigniew K. Brzezinski. (Cambridge, Mass.: Harvard University Press. 1956. Pp. xii, 346.)”, The American Historical Review 63, 1958, no. 2.

Silverman D., Interpreting Qualitative Data, Los Angeles-London-New Delhi 2014.

Sullivan J.L., Feldman S., Quantitative Applications in the Social Sciences: Multiple Indicators, Thousand Oaks, CA 1979.

Timasheff N., "Totalitaryzm. Despotyzm. Dyktatura", [in:] Totalitaryzm. Materiały z konferencji zorganizowanej przez Amerykańska Akademię Sztuk i Nauk w marcu 1953 r., ed. C.J. Friedrich, Warszawa 2019.

Tismaneanu V., Fantasies of Salvation: Democracy, Nationalism, and Myth in Post-Communist Europe, Princeton, NJ 2009.

Voegelin E., "Gnostische Politik", Merkur 6, 1952, no. 4.

Voegelin E., The New Science of Politics: An Introduction, Chicago-London 1987 [1952]. 